\title{
МИГРАЦИЯ СЕВЕРОКАВКАЗСКОГО НАСЕЛЕНИЯ С ГОР НА РАВНИНУ: ИСТОКИ РАЗНООБРАЗИЯ
}

Статья рассматривает влияние миграции с гор на равнину на брачность и рождаемость горских народов Дагестана. На протяжении нескольких последних десятилетий она носит массовый характер, в связи с чем важной задачей социальной политики является адаптация переселенцев в местах их нового расселения. Один из факторов, который необходимо учитывать при решении задач адаптации-это брачно-репродуктивное поведение переселенцев. Если его характеристики не меняются или мало меняются в результате миграции, то возможны существенные контрасты между переселенцами и коренными жителями новых для них территорий. Через сопоставление результатов количественного полевого исследования среди переселенцев с горных территорий Дагестана мы показываем, что миграция с гор на равнину может сопровождаться разными сценариями брачно-репродуктивного поведения: возможен как отход от его характеристик, наблюдаемых в горах, так и сохранение этих характеристик не только в первом, но и в последующих поколениях переселенцев. Этот вывод обосновывается в статье статистическими методами. Сопоставляется разные миграционные потоки и демонстрируется, что в некоторых из них между переселенцами и теми, кто остался на «исторической родине», имеются статистически значимые различия по характеристикам брачно-репродуктивного поведения, а в некоторых - нет. Кроме того, для части сообществ регрессионные модели показывают значимость параметров «миграционной истории» женщин для их возраста вступления в брак и числа детей, а для других такой значимости не обнаруживается. Обсуждаются гипотезы о том, почему в одних случаях брачно-репродуктивное поведение «устойчиво» к переселению с гор на равнину, а в других оно меняется

Константин Игоревич Казенин- к.ф.н., директор, Центр региональных исследований, ИПЭИ РАНХиГС, Москва, Россия. Электронная почта: kz@ranepa.ru 
в результате переселения. Делается вывод о необходимости учета выявленного разнообразия при планировании социальной политики на территориях, куда идет миграция горского населения.

Ключевые слова: миграция, брачность, рождаемость, Дагестан, адаптация мигрантов

DOI: $10.17323 / 727-0634-2019-17-1-23-38$

Миграция населения ставит непростые задачи для социальной политики государства. Среди этих задач- обеспечение полноценной адаптации мигрантов на принимающей территории. Одним из факторов, влияющих на адаптацию мигрантов, является их демографическое поведение. В случае, если в сфере брака и деторождения мигранты сохраняют особенности, характерные для их исторической родины (например, раннюю брачность, высокую рождаемость), то государство сталкивается с рядом особых вызовов. Во-первых, высокая рождаемость в крупных сообществах иностранных или внутренних мигрантов требует адекватной «настройки» социальных учреждений с тем, чтобы семьи с детьми могли получить необходимые услуги. Во-вторых, вероятно возникновение различий между переселенцами и другими жителями территорий, на которые идет миграция, по возрасту вступления женщин в брак и при рождении первого ребенка, по размеру семей. Это, в свою очередь, закрепляет социокультурные контрасты между мигрантами и их соседями и, следовательно, требует от государства и НКО особых усилий для полноценной адаптации мигрантов.

Демографические исследования говорят о возможности разных сценариев влияния миграции на рождаемость (см.: Захаров, Сурков 2009; Казенин 2017; Kulu 2005; Kulu, Gonzalez-Ferrer 2014). В частности, возможно восприятие переселенцами тех репродуктивных установок, которые они видят у населения принимающей территории, или сохранение установок, доминировавших в том социуме, где они жили в детстве и юности. В последнем случае контрасты с жителями принимающей территории могут наблюдаться и у мигрантов первого поколения, выросших на своей исторической родине, и у мигрантов второго и последующих поколений, если их детство и юность проходили в замкнутом сообществе переселенцев.

В последние десятилетия одной из траекторий внутренней миграции является миграция населения гор и предгорий Северного Кавказа на равнину. Она приняла массовый характер начиная с 1960-х гг. и обрела «второе дыхание» после распада СССР. По «дальности» эта миграция делится на внутрирегиональную- с гор на равнину в пределах одной республики (см.: Османов 2000; Казенин 2012); в пределах Юга России (Белозеров 2005: 54-169); и миграцию в более отдаленные от Кавказа части РФ, прежде всего в Московский регион, Поволжье и Западную Сибирь (Карпов, Капустина 2011). Цель этой статьи- установить пути влияния миграции горцев 
Северного Кавказа на равнину на их брачно-репродуктивное поведение. Полевое исследование, результаты которого отражены ниже, не претендует на полноту изучения данного явления, однако позволяет на примерах показать, что в одних сообществах переселенцев миграция с гор на равнину ведет к существенным изменениям параметров рождаемости и брачности, а в других - оставляет их практически «нетронутыми». Обнаружив это разнообразие, учет которого необходим при планировании социальной политики в тех регионах, куда идет миграция горцев, мы обосновываем одну из гипотез о его причинах.

\section{Характеристика данных}

Наиболее адекватным способом исследования взаимосвязи миграции и брачно-репродуктивного поведения применительно к коренным народам Северного Кавказа, на наш взгляд, служит исследование моноэтничных групп мигрантов, являющихся выходцами с небольшой горной территории (например, из одного или двух соседних районов), в сопоставлении с населением их «исторической родины», не совершившим миграции. Дело в том, что на Северном Кавказе сохранены значительные межтерриториальные и межэтнические различия по характеристикам брачности и рождаемости (Богоявленский 2012; Казенин, Козлов 2017а). Игнорирование различий между территориями, откуда идет миграция, может привести к искажениям при исследовании влияния миграции на рождаемость. Этого риска можно избежать, по отдельности исследуя миграцию с территорий, относительно гомогенных по рождаемости.

Переселенцы с Кавказских гор на равнину в значительной мере погружаются в новую для себя среду. Очевидные отличия касаются состава социальных связей: среди тех, с кем они контактируют в повседневной жизни на равнине, гораздо выше, чем в горах, доля людей, не принадлежащих к их сельской общине и этносу. Это происходит даже в тех случаях (по нашим наблюдениям, все же довольно редких), когда выходцы из одного горного села расселяются на равнине компактно. Такие характеристики северокавказских горных районов, как моноэтничность большинства населенных пунктов и нечастое заселение в них представителей других сельских общин, на равнине присутствуют гораздо слабее. Также меняется и структура занятости населения благодаря сокращению занятых в сельском хозяйстве и, как правило, расширяются возможности для получения образования и работы по найму. Вместе с тем исследователи многократно отмечали, что для северокавказских переселенцев с гор и их потомков, особенно в Дагестане, характерно поддержание связей с выходцами из родного села (Карпов 2010; Карпов, Капустина 2011). Часто это выражается не только в соблюдении ежегодных ритуалов празднования «дней села» или «дней района», но и в совместном ведении бизнеса, в большом количестве браков, заключаемых 
на равнине между бывшими горцами-односельчанами или их потомками. Если учитывать выводы исследований влияния социальных связей (сетей) на принятие индивидом решений, касающихся брака и рождения детей (Kohler 2000), то в описанной ситуации можно ожидать как отход от тех характеристик рождаемости и брачности, которые наблюдаются в горах, так и их сохранение на равнине. На вопрос о том, какая из тенденций оказывается «сильнее», ответить может эмпирическое исследование.

Таблий 1

Численность и доля табасаранского населения в равнинной части Дагестана и аварского населения в Кизлярском районе, городах Кизляр и Астрахань (по данным Всесоюзных и Всероссийских переписей населения)

\begin{tabular}{|c|c|c|c|c|c|c|}
\hline & 1959 & 1970 & 1979 & 1989 & 2002 & 2010 \\
\hline \multicolumn{7}{|c|}{ Табасаранцы } \\
\hline \multirow[t]{2}{*}{ Дербентский р-н } & 826 & 6736 & 10833 & 8496 & 9229 & 9807 \\
\hline & $(3 \%)$ & $(13,2 \%)$ & $(17,9 \%)$ & $(13,3 \%)$ & $(10,7 \%)$ & $(9,9 \%)$ \\
\hline \multirow[t]{2}{*}{ Дербент } & 1522 & 3296 & 6183 & 8776 & 15606 & 18839 \\
\hline & $(3,2 \%)$ & $(5,8 \%)$ & $(9,2 \%)$ & $(11,3 \%)$ & $(15,4 \%)$ & $(15,8 \%)$ \\
\hline \multirow[t]{2}{*}{ Дагестанские огни } & & 1195 & 2042 & 6764 & 9359 & 12901 \\
\hline & & $(11,4 \%)$ & $(12,4 \%)$ & $(31,3 \%)$ & $(35,3 \%)$ & $(46,2 \%)$ \\
\hline \multicolumn{7}{|c|}{ Авариь } \\
\hline \multirow[t]{2}{*}{ Кизлярский р-н } & 862 & 4430 & 8163 & 14288 & 22907 & 31371 \\
\hline & $(4 \%)$ & $(10,5 \%)$ & $(19,7 \%)$ & $(29,9 \%)$ & $(39,7 \%)$ & $(46,62 \%)$ \\
\hline \multirow[t]{2}{*}{ Кизляр } & 146 & 607 & 1275 & 3390 & 7467 & 12122 \\
\hline & $(0,4 \%)$ & $(2 \%)$ & $(4,1 \%)$ & $(8,7 \%)$ & $(15,4 \%)$ & $(21,94 \%)$ \\
\hline Астрахань & & & & & $\begin{array}{r}4217 \\
(0,4 \%)\end{array}$ & $\begin{array}{r}4719 \\
(0,5 \%)\end{array}$ \\
\hline
\end{tabular}

Мы рассмотрим влияние миграции на рождаемость в двух сообществах переселенцев дагестанского происхождения, сходных по интенсивности и времени миграции. Это, во-первых, аварцы, мигрирующие из двух соседних друг с другом районов горного Дагестана (Ботлихского и Цумадинского) в равнинную часть Дагестана (Кизлярский район и город Кизляр) и в Астрахань. Во-вторых, это табасаранцы, мигрирующие с гор на равнину в пределах южного Дагестана (в города Дербент и Дагестанские Огни и в Дербентский район). Оба народа, включенных в наше исследование, относятся к крупным этносам Дагестана. Численность аварцев, по данным Всероссийской переписи населения 2010 г., в Дагестане составила 850001 чел., а табасаранцев- 118500 чел. Аварцы- первый по численности этнос всего региона, а табасаранцы-второй, вслед за лезгинами 
этнос южного Дагестана. Стоит отметить, что некоторые группы жителей Ботлихского и Цумадинского районов в языковом отношении отличается от аварцев, хотя и родственны им; иногда эти группы считаются отдельными (суб)этносами (Арутюнов и др. 2002), однако мы при составлении выборки не учитывали эти различия.

Миграция табасаранцев с гор началась в 1960-е гг. в рамках организованного переселения после сильного землетрясения в горах (Османов 2000: 250-276) и продолжалась в позднесоветское и постсоветское время, сделав табасаранцев крупнейшим по численности этносом во втором по общему числу жителей городе южного Дагестана- Дагестанских Огнях (табл. 1). Из крупных миграционных потоков в современном Дагестане это один из самых «коротких», так как расстояние между ареалами компактного расселения табасаранцев в горах и на равнине- менее 100 км. Главным мотивом переселения были и остаются более благоприятные социально-бытовые условия на равнине.

Первые аварцы, выходцы из Ботлихского и Цумадинского районов, появились на дагестанской равнине еще в 1950-е гг. в ходе организованных советской властью переселений. Миграция заметно активизировалась начиная с 1980-х гг., в результате чего сейчас имеются мигранты первого, второго и даже третьего поколений. Именно выходцы из Ботлихского и Цумадинского районов составили большинство аварского населения в городе Кизляр и в Кизлярском районе, став там в 1990-е гг. одним из наиболее сплоченных и влиятельных сообществ на фоне миграции из этой части Дагестана русского населения (Карпов 2010:427-436). В сельской местности они проживают как в моноэтничных селах, так и в селах, где совместно с ними живут люди других национальностей. Что касается миграции аварцев в Астрахань, то ее тоже совершали в основном выходцы из двух указанных районов (главным образом из двух сел) начиная с 1980-х гг., и связана она с открывшимися возможностями для торговли на рынках в этом городе. По сей день большинство семей выходцев из Ботлихского и Цумадинского района в Астрахани проживает в районе рынка Большие Иссады в старой части города и так или иначе связано с торговлей на нем. Официальная статистика содержит лишь данные о численности национальностей, но не выходцев из отдельных районов на территориях миграции, однако полевые данные позволяют утверждать, что большинство аварцев в Кизляре и Кизлярском районе и почти все в Астрахани (табл. 1) являются выходцами именно из Ботлихского и Цумадинского районов.

Исследование взаимосвязи миграции и рождаемости в этих двух сообществах переселенцев основано на результатах опроса женщин возраста 16-39 лет, проведенного в январе- июле 2017 г. Опрос проводился как среди мигрантов, так и среди жителей горных территорий, откуда идет миграция. Всего опрошено 520 женщин аварской национальности и 588 табасаранской. Число опрошенных горянок и жительниц равнины среди респонденток 
табасаранской национальности было почти равным, а среди респонденток аварской национальности горянки составили 40\%; эти пропорции выбраны на основании оценок соотношения горского и равнинного населения в двух сообществах. В обеих подгруппах обеспечено почти равное представительство всех пятилетних возрастных групп (16-19, 20-24, 25-29, 30-34 и 35-39 лет). Опрос проводился специально подготовленными местными интервьюерами с последующим телефонным контролем. На каждой территории процедура выбора респонденток не противоречила методике составления случайных выборок. В анкетах, предлагавшихся респонденткам, были вопросы, касающиеся основных фактов «жизненной истории» женщины (год и месяц рождения, место рождения, годы и направления переездов, образование, трудовая занятость, брачный статус, возраст вступления в брак, количество детей и возраст каждого из них и т.д.). Также содержались вопросы, позволявшие оценить степень личной религиозности женщины (считает ли она важным религиозное воспитание детей, считает ли допустимым аборт) и степень традиционности уклада семьи, в которой выросла и в которой проживает женщина (самостоятельно ли она приняла решение о вступлении в брак или вышла замуж по совету родственников; работала ли за пределами домохозяйства после вступления в брак). Включение двух последних групп вопросов связано с тем, что предшествующие исследования показали значимость факторов, которых эти вопросы касаются, для рождаемости в Дагестане (Казенин, Козлов 2017б).

\section{Диаспора и «историческая родина»: различия брачно-репродуктивного поведения}

Опрос показал, что распределение респонденток по их «миграционным историям» (то есть по месту рождения, месту проживания на момент опроса и возрасту миграции) в двух сообществах различалось мало (табл. 2). По характеристикам брачности и рождаемости сходство между двумя сообществами оказалось не таким полным. В таблице 3 представлены средние значения возраста вступления в брак и число детей к двум возрастам у респонденток обоих сообществ, с противопоставлениями по месту рождения и по месту проживания. Различия обнаруживаются по возрасту вступления в брак: у табасаранок этот показатель у родившихся в горах и проживающих в горах значимо ниже, чем соответственно у родившихся на равнине и проживающих на равнине; у аварок значимых различий по этому показателю между «горными» и «равнинными» респондентками не наблюдается. Значимых различий по числу детей к 25 и 35 годам не обнаружено ни в одном из двух сообществ.

Бо́льшие возможности для определения значимости миграции для брачно-репродуктивного поведения дают регрессионные модели, где возможно исследовать влияние на параметры брачно-репродуктивного поведения 
одновременно целой совокупности признаков. В качестве зависимых в моделях рассматриваются два параметра: возраст вступления женщины в брак и число детей у женщины на момент опроса. Независимых параметров, отражающих миграционный статус женщины, в моделях два: место рождения (горы или равнина) и место проживания на момент опроса. Бесспорно, такая параметризация заметно «огрубляет» миграционные истории респонденток, не различая мигранток первого поколения, проживающих на равнине, по возрасту переезда. Однако определение точного количества лет, проведенных ими на равнине, оказалось проблематичным, хотя такая попытка в ходе опроса делалась: многие респондентки затруднялись назвать точный год/возраст переезда, отмечая, что в определенные периоды жили «то в горах, то на равнине», проводя сопоставимые доли времени и там, и там.

Таблииа 2

Доли респонденток с разными характеристиками места проживания и рождения в выборках

\begin{tabular}{|c|c|c|c|c|c|c|}
\hline & 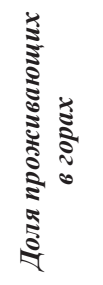 & 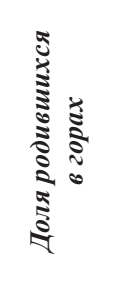 & 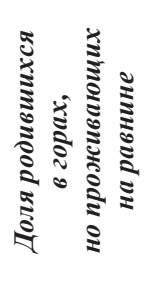 & 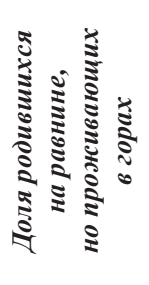 & 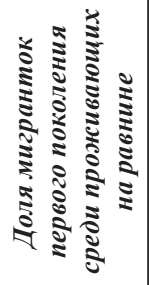 & 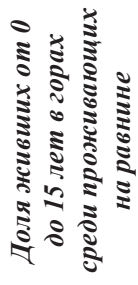 \\
\hline Табасаранки & $48,4 \%$ & $54,82 \%$ & $11,25 \%$ & $4,82 \%$ & $19,9 \%$ & $10,2 \%$ \\
\hline Аварки & $40,1 \%$ & $52,9 \%$ & $14,82 \%$ & $2 \%$ & $25,0 \%$ & $10,2 \%$ \\
\hline
\end{tabular}

В таблице 4 представлены линейные модели, зависимой переменной в которых является возраст при вступлении в брак. Модели строились отдельно для респонденток аварской и табасаранской национальности, однако показаны только модели, построенные для вторых, поскольку у первых параметры миграционной истории оказались незначимы. У табасаранок значимо снижают возраст вступления в брак факт рождения и факт проживания в горах (модели (1) и (2)). При одновременном включении в модель и параметра места рождения, и параметра места проживания, значимым остается место рождения (модель (3)). В модели в качестве независимых также включены характеристики, которые оказались значимыми для возраста вступления в брак без параметров места рождения и проживания: это факт учебы после окончания средней школы, факт работы (трудовой деятельности вне домохозяйства) на момент опроса и факт самостоятельного решения о вступлении в брак (в противоположность вступлению в брак по решению родителей). Эти же характеристики оказались среди значимых для возраста вступления в брак для дагестанского населения 
в целом, согласно опросу, проведенному в 2018 г. Модели с этими тремя признаками без переменных места проживания и места рождения здесь не показаны. Как видно из моделей (4)-(6), у табасаранок значимость места рождения сохраняется и при включении в модель этих дополнительных признаков (табл. 4). Это подтверждает значимость места рождения для возраста вступления в брак. Нами были построены модели с такими же наборами независимых параметров и с числом детей у женщины на момент опроса в качестве зависимого параметра (модели с регрессией Пуассона; здесь не показаны). В них значимости места проживания и места рождения ни для одного из сообществ не обнаружилось, что согласуется с отсутствием значимых различий по этим признакам для числа детей в таблице 3 .

Таблицуа 3

Различия демографических показателей респонденток по месту рождения и месту проживания (результат применения двустороннего t-теста)

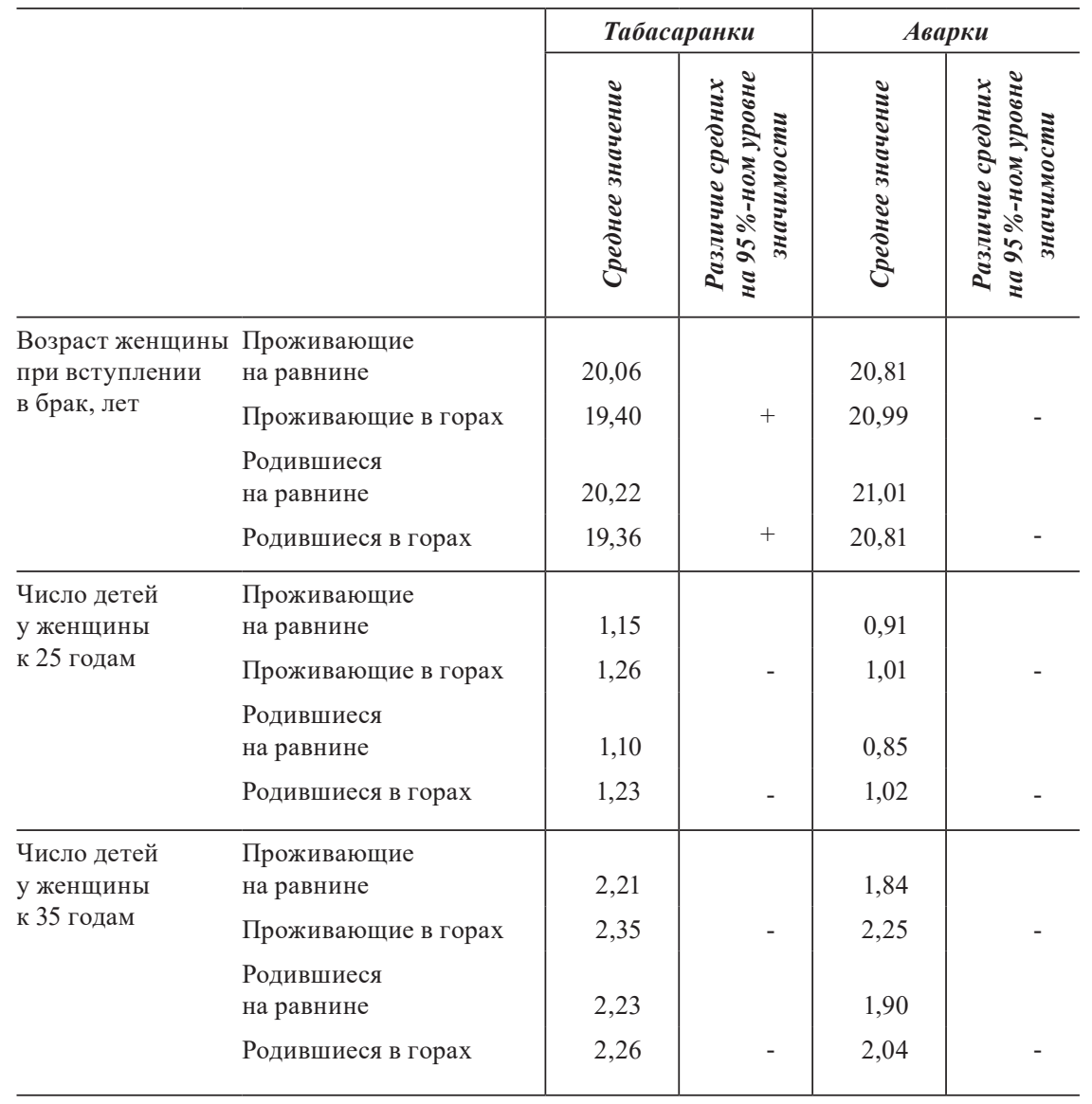


Таблий 4

Модели с возрастом вступления в брак в качестве зависимого показателя, построенные на основе опроса женщин табасаранской национальности (здесь и далее *p< $<, 1, * * \mathbf{p}<0,05, * * * p<0,001 ;$ в скобках-стандартная ошибка)

\begin{tabular}{|c|c|c|c|c|c|c|}
\hline & (1) & (2) & (3) & (4) & (5) & (6) \\
\hline Возраст & $\begin{array}{r}0,121^{* * *} \\
(0,018)\end{array}$ & $\begin{array}{r}0,120^{* * *} \\
(0,018)\end{array}$ & $\begin{array}{r}0,121 * * * \\
(0,018)\end{array}$ & $\begin{array}{r}0,116^{* * *} \\
(0,018)\end{array}$ & $\begin{array}{r}0,132 * * * \\
(0,019)\end{array}$ & $\begin{array}{r}0,128^{* * *} \\
(0,018)\end{array}$ \\
\hline $\begin{array}{l}\text { Рождение в горах } \\
(1-\text { да, } 0-\text { нет) }\end{array}$ & $\begin{array}{r}-0,868 * * * \\
(0,226)\end{array}$ & & $\begin{array}{r}-0,805^{* * *} \\
(0,291)\end{array}$ & $\begin{array}{l}-0,547 * \\
(0,298)\end{array}$ & $\begin{array}{r}-0,888 * * * \\
(0,295)\end{array}$ & $\begin{array}{r}-0,805 * * * \\
(0,296)\end{array}$ \\
\hline $\begin{array}{l}\text { Проживание } \\
\text { в горах (1- да, } \\
0 \text { - нет) }\end{array}$ & & $\begin{array}{r}-0,714 * * * \\
(0,219)\end{array}$ & $\begin{array}{l}-0,098 \\
(0,287)\end{array}$ & $\begin{array}{r}0,251 \\
(0,290)\end{array}$ & $\begin{array}{r}0,003 \\
(0,293)\end{array}$ & $\begin{array}{l}-0,072 \\
(0,292)\end{array}$ \\
\hline $\begin{array}{l}\text { Учеба после } \\
\text { окончания } \\
\text { средней школы } \\
\text { (1-да, } 0 \text { - нет) }\end{array}$ & & & & $\begin{array}{r}0,809 * * * \\
(0,239)\end{array}$ & & \\
\hline $\begin{array}{l}\text { Работа на момент } \\
\text { опроса ( } 1-\text { да, } \\
0-\text { нет) }\end{array}$ & & & & & $\begin{array}{l}-0,421^{*} \\
(0,249) \\
\end{array}$ & \\
\hline $\begin{array}{l}\text { Самостоятельно } \\
\text { приняла решение } \\
\text { о выходе замуж } \\
(1-\text { да, } 0-\text { нет) }\end{array}$ & & & & & & $\begin{array}{r}(0,493)^{* *} \\
(0,237) \\
\end{array}$ \\
\hline $\mathrm{R}^{2}$ & 0,138 & 0,121 & 0,138 & 0,157 & 0,143 & 0,152 \\
\hline $\mathrm{N}$ & 392 & 414 & 392 & 384 & 389 & 377 \\
\hline
\end{tabular}

Тот факт, что у табасаранцев при включении в модель места проживания и места рождения значимым остается только второе, позволяет предположить, что в этом сообществе различия по возрастной модели брачности в большей степени определяются именно местом рождения, а не проживания женщины. Если это так, то среди табасаранок, проживающих на равнине, можно ожидать различия по возрасту вступления в брак между мигрантками в первом и во втором поколении. Это ожидание подтверждается расчетами (таблица 5). При этом у аварок, проживающих на равнине, разница между первым и вторым поколением мигранток незначима. Принадлежность к мигранткам второго поколения оказывается негативно значимой также для числа детей, но снова только для табасаранок (табл. 6). 
Таблицуа 5

Модели с возрастом вступления в брак в качестве зависимого показателя, только для женщин табасаранской национальности, проживающих на равнине

\begin{tabular}{|c|c|c|c|c|}
\hline & (1) & (2) & (3) & (4) \\
\hline Возраст & $\begin{array}{r}0,147 * * * \\
(0,027) \\
\end{array}$ & $\begin{array}{r}0,134 * * * \\
(0,027) \\
\end{array}$ & $\begin{array}{r}0,165^{* * *} \\
(0,028) \\
\end{array}$ & $\begin{array}{r}0,152^{* * *} \\
(0,028) \\
\end{array}$ \\
\hline $\begin{array}{l}\text { Мигрант второго поколения } \\
(0-\text { первого, } 1 \text { - второго) }\end{array}$ & $\begin{array}{l}0,622^{*} \\
(0,374)\end{array}$ & $\begin{array}{r}0,184 \\
(0,387)\end{array}$ & $\begin{array}{r}0,792^{* *} \\
(0,377)\end{array}$ & $\begin{array}{l}0,655^{*} \\
(0,384)\end{array}$ \\
\hline $\begin{array}{l}\text { Учеба после окончания средней школы } \\
(0-\text { нет, } 1 \text { - да) }\end{array}$ & & $\begin{array}{r}1,248 * * * \\
(0,356)\end{array}$ & & \\
\hline $\begin{array}{l}\text { Работа на момент опроса } \\
(0-\text { нет, } 1 \text { - да) }\end{array}$ & & & $\begin{array}{r}-0,885^{* *} \\
(0,363) \\
\end{array}$ & \\
\hline $\begin{array}{l}\text { Сама приняла решение о вступлении } \\
\text { в брак (0- нет, } 1 \text { - да) }\end{array}$ & & & & $\begin{array}{r}0,286 \\
(0,368)\end{array}$ \\
\hline$\overline{\mathrm{R}^{2}}$ & 0,153 & 0,200 & 0,177 & 0,161 \\
\hline $\mathrm{N}$ & 187 & 183 & 186 & 180 \\
\hline
\end{tabular}

Таблицуа 6

Зависимость числа детей от миграционного «поколения» женщины (модели с регрессией Пуассона, только для проживающих на равнине; контрольный параметр- возраст на момент опроса)

\begin{tabular}{l|r|r}
\hline \multicolumn{1}{c|}{ Зависимая } & $\begin{array}{c}\text { Taб. } \\
\text { Число детей }\end{array}$ & $\begin{array}{c}\text { Aвар. } \\
\text { Число детей }\end{array}$ \\
\hline $\begin{array}{l}\text { Мигрант первого поколения } \\
\text { (REF: мигрант второго поколения) }\end{array}$ & $0,452(0,1992)^{* *}$ & $-0,037(0,1802)$ \\
\hline $\mathrm{N}$ & 260 & 291 \\
\hline
\end{tabular}

Резюмируем результаты. У аварцев значимости места проживания, места рождения, а также принадлежности к мигрантам определенного поколения не обнаруживается. Это означает «единство» горянок и жительниц равнины по брачно-репродуктивному поведению в данном этническом сообществе. У табасаранок миграция на равнину сопровождается снижением рождаемости и повышением возраста женщины при вступлении в брак, причем наиболее значимым для этого фактором оказалось рождение женщины на равнине. 


\section{Разнообразие репродуктивных сценариев среди мигрантов: возможные причины и последствия для социальной политики}

На примере двух дагестанских этнических сообществ, активно мигрировавших с гор на равнину в течение последних десятилетий, мы показали, что взаимосвязь миграции и брачно-репродуктивного поведения при переселении с гор на равнину может быть разной. Один из возможных вариантов- «устойчивость» возраста вступления в брак и уровня рождаемости к миграции, второй- изменение этих параметров в результате переезда на равнину. Закономерно возникает вопрос о том, что может быть причиной реализации того или другого варианта в переселенческом сообществе.

Прежде всего отметим, что в рассматриваемом случае неверны две гипотезы, которые могли бы казаться наиболее «естественными». Первая состоит в том, что бо́льшая слитность по демографическим характеристикам наблюдается для сообщества, у которого территория миграции меньше отстоит от исторической родины. В нашем примере имеет место в точности противоположное: табасаранцы дагестанской равнины проживают на значительно меньшем удалении от своей исторической родины, чем аварцы Кизляра и, тем более, Астрахани. Вторая ложная гипотеза состоит в том, что у табасаранцев отход переселенцев от «горских стандартов» брачно-репродуктивного поведения связан с большей ассимилированностью табасаранской общины на равнине по сравнению с аварцами. Против этого говорит то обстоятельство, что процент межэтнических браков на равнине у аварок и табасаранок оказался одинаково низок (менее $5 \%$, по данным нашего опроса).

Объяснение, которое кажется более перспективным, касается различий сообществ по степени «традиционности» семейного уклада. Под семейной «традиционностью» мы вслед за (Szołtysek et al. 2016) понимаем комплекс признаков, связанных в первую очередь с действием в семье гендерных иерархий (ограниченность роли жены хозяйством и воспитанием детей) и поколенческих иерархий (зависимость младшего поколения взрослых членов семьи от старшего в принятии важных жизненных решений). В статье «Возраст материнства в Дагестане» (Казенин, Козлов 2017a) показано, что на современном Северном Кавказе контрасты по таким признакам наблюдаются не только между горами и равниной, городом и селом, но могут сохраняться и, например, между выходцами из разных сельских сообществ, проживающих в городах. Данные опроса указывают на заметные различия между двумя изучаемыми сообществами по нескольким признакам, характеризующим семейный традиционализм. Так, доля заявивших, что самостоятельно (а не по совету родителей) приняли решение о вступлении в брак, у табасаранок составила $58,1 \%$, а среди аварок-40,5\%. Доля учившихся после окончания средней школы среди табасаранок оказалась выше, чем у аварок примерно на 10 п.п. 
Кроме контраста по «традиционности» семейного уклада, очевиден и контраст по личной религиозности женщин: среди аварок религиозное воспитание детей сочли важным $86,5 \%$, а среди табасаранок- $45,4 \%$. Все эти цифры хорошо согласуются с нашими неформализованными полевыми наблюдениями над двумя сообществами. Жители Цумадинского и Ботлихского районов Дагестана и выходцы оттуда в целом отличаются крепкими родственными связями, большой (хотя переменной от села к селу) ролью ислама в жизни сообществ, плотным контролем старших родственников за жизнью молодежи, особенно девушек. Что касается табасаранского сообщества, то для него, как и для других народов южного Дагестана, можно наблюдать более скромную роль религии в повседневной жизни обычной семьи, слабые общинные связи между выходцами из одного села. Как видим, это сочетается с более заметными контрастами и по параметрам рождаемости между мигрантами и оставшимися на исторической родине.

Таблица 7

Частоты некоторых признаков среди респонденток, по национальности и месту проживания

\begin{tabular}{|c|c|c|c|c|c|}
\hline & & \multicolumn{2}{|c|}{ Табасаранки } & \multicolumn{2}{|c|}{ Аварки } \\
\hline & & de & 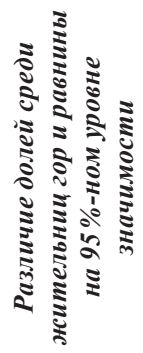 & $d^{\circ}$ & 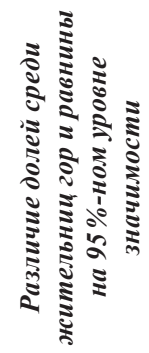 \\
\hline $\begin{array}{l}\text { Учившиеся } \\
\text { после окончания } \\
\text { средней школы }\end{array}$ & $\begin{array}{l}\text { Проживающие } \\
\text { на равнине } \\
\text { Проживающие } \\
\text { в горах }\end{array}$ & $\begin{array}{l}59 \\
62\end{array}$ & - & $\begin{array}{l}49 \\
58\end{array}$ & - \\
\hline $\begin{array}{l}\text { Самостоятельно } \\
\text { принявшие решение } \\
\text { о вступлении в брак }\end{array}$ & $\begin{array}{l}\text { Проживающие } \\
\text { на равнине } \\
\text { Проживающие } \\
\text { в горах }\end{array}$ & 66 & + & $\begin{array}{l}38 \\
44\end{array}$ & - \\
\hline $\begin{array}{l}\text { Считающие важным } \\
\text { религиозное } \\
\text { воспитание детей }\end{array}$ & $\begin{array}{l}\text { Проживающие } \\
\text { на равнине } \\
\text { Проживающие } \\
\text { в горах }\end{array}$ & 57 & + & $\begin{array}{l}81 \\
95\end{array}$ & + \\
\hline
\end{tabular}


С другой стороны, две рассматриваемые этнические группы, судя по данным опроса, различаются по тому, насколько и «с каким знаком» миграция на равнину повлияла на социальные характеристики, индицирующие «традиционность» семейного уклада и личную религиозность. В таблице 7 показаны доли респондентов, обладающих некоторыми из этих характеристик, отдельно для жителей гор и равнины. Доля женщин, самостоятельно принявших решение о вступлении в брак, у табасаранцев на равнине значимо выше, чем в горах, в то время как у аварцев разница между горами и равниной здесь незначима. Кроме того, у табасаранцев, проживающих на равнине, значимо меньше по сравнению с горами доля женщин, считающих важным религиозное воспитание детей, в то время как у аварцев на равнине доля таковых, наоборот, значимо выше, чем в горах. Эти признаки позволяют предположить, что переселение с гор на равнину у одного из исследуемых этносов (табасаранцев) связано с определенной «секуляризацией» и размыванием традиционного семейного уклада, в то время как у другого (аварцев) такого эффекта мы не видим. Важная параллель состоит в том, что у одного, но не у другого этноса между жителями гор и равнины имеются значимые различия и по характеристикам рождаемости.

\section{Заключение}

Исследование двух кейсов миграции с гор на равнину показало, что такая миграция на Северном Кавказе может по-разному сказываться на характеристиках брачности и деторождения. В одних миграционных потоках данные опросов указывают на значимые различия между переселенцами и теми, кто остается на исторической родине, а в других такие различия отсутствуют. Социальная политика, направленная на адаптацию северокавказских переселенцев в местах их проживания (в том числе в других регионах России), должна учитывать это многообразие. Сохранность у некоторых групп переселенцев горского происхождения тех характеристик демографического поведения и семейного уклада, которые наблюдаются на их исторической родине,--это не повод утверждать, что адаптация переселенцев якобы невозможна, а стимул к поиску таких форм адаптации, которые были бы эффективны и при наличии определенных социокультурных контрастов между переселенцами и жителями принимающих территорий.

\section{Выражение признательности}

Статья отражает результаты исследований по НИР РАНХиГС 2017 г. «Факторы рождаемости и динамика демографических процессов среди мигрантовмусульман Северного Кавказа» и НИР РАНХиГС 2018 г. «Влияние социокультурных факторов на результаты государственной поддержки рождаемости в Российской Федерации». 


\section{Список источников}

Арутюнов С.А., Османов А.И., Сергеева Г.А. (ред.) (2002) Народы Дагестана. М.: Наука. Белозеров В.С. (2005) Этническая карта Северного Кавказа. М.: О.Г.И.

Богоявленский Д. Д. (2012) Перепись 2010: этнический срез. Демоскоn Weekly, 31.05.2012. Доступно по ссылке: http://demoscope.ru/weekly/2012/0531/tema01.php (дата обращения: 27 мая 2016).

Захаров С.В., Сурков С.В. (2009) Миграционный опыт и рождаемость в послевоенных поколениях россиян. С. В. Захаров, Т. М. Малева, О.В. Синявская (ред.) Родители и дети, мужчины и женщины в семье и обществе. Bып.2. М.: НИСП: 45-118.

Казенин К.И. (2012) Элементы Кавказа: земля, власть и идеология в северокавказских республиках. M.: REGNUM.

Казенин К.И. (2017) Рождаемость в семьях мигрантов: данные, гипотезы, модели (обзор зарубежных исследований). Демографическое обозрение, 4 (4): 6-79.

Казенин К.И., Козлов В. А. (2016) Омоложение материнства в Дагестане: тенденция или артефакт. Демографическое обозрение, 3 (3): 100-123.

Казенин К.И., Козлов В.А. (2017а) Возраст материнства в Дагестане: значимость этнического фактора в условиях модернизации. Народонаселение, 21 (1): 46-58.

Казенин К.И., Козлов В.А. (2017б) Особенности брачно-репродуктивного поведения в Республике Дагестан: их причины и социально-экономические последствия. Вестник Института экономики РАН, 11 (2): 65-81.

Карпов Ю. Ю. (2010) Переселение горцев Дагестана на равнину: к истории развития процесса и социокультурным его последствиям. Ю.Ю. Карпов (ред.) Традииии народов Кавказа в меняющемся мире. СПб.: Петербургское востоковедение: 402-447.

Карпов Ю. Ю., Капустина Е. Л. (2011) Гориы после гор. СПб.: Петербургское востоковедение.

Османов А.И. (2000) Аграрные преобразования в Дагестане и переселение гориев на равнину (20-70-е годы ХХ в.). Махачкала: ДНЦ РАН.

Kohler H.-P. (2000) Social Interaction and Fluctuations in Birth Rates. Population Studies, 54 (2): 223-238.

Kulu H. (2005) Migration and Fertility: Competing Hypothesis Reexamined. European Journal of Population Research, (21): 51-87.

Kulu H., Gonzalez-Ferrer A. (2014) Family Dynamics among Immigrants and Their Descendants in Europe: Current Research and Opportunities. European Journal of Population, (30): 411-435.

Szołtysek M., Poniat R., Gruber S., Klüsener S. (2016) The Patriarchy Index: a New Measure of Gender and Generational Inequalities in the Past. MPIDR Working Papers-014. 
Konstantin Kazenin

\section{MIGRATION FROM THE MOUNTAINS TO THE VALLEY IN THE NORTH CAUCASUS: THE CHALLENGES OF DIVERSITY}

The paper deals with impact of mountains-to-valley migration on marital and fertility behavior among the indigenous peoples of Dagestan, in the North Caucasus, Russia. This migration has been rather intensive during recent decades, making the adaptation of these migrants a substantial challenge for state social policy. One issue relevant for migrant adaptation is whether and how migration changes demographic characteristics like age at marriage, number of children per woman, etc. If contrasts on these characteristics between migrants and the native population of immigration sites are observed, this may constitute a special challenge in migrant adaptation. The paper considers data on two migrant communities relocating from the mountains of Daghestan to the valley part of that region or to other regions of Russia. Analyzing the survey results, we argue that the impact of the mountains-to-valley migration on matrimonial and reproductive behavior can be different in different communities. For one of the communities under study, differences between migrants and those who stay in the mountains are significant, whereas for the other one they are not. Moreover, for the former, but not for the latter community, the parameters of 'migration history', such as age at migration, are significant in determining the woman's age at marriage and the number of children in regression models. Thus, surprisingly, migration flows geographically very close to each other appear to be different in sustainability of their marital and fertility patterns to migration. Possible accounts for this diversity are discussed, as well as the implications this has for social policy.

Key words: migration, marriage, fertility, Dagestan, adaptation of migrants

DOI: $10.17323 / 727-0634-2019-17-1-23-38$

\section{References}

Arutjunov S. A., Osmanov A. I., Sergeeva G. A. (eds.) (2002) Narody Dagestana [Peoples of Dagestan]. Moscow: Nauka.

Belozerov V. S. (2005) Etnicheskaja karta Severnogo Kavkaza [An Ethnic Map of the North Caucasus]. Moscow: O.G.I.

Bogojavlenskij D. D. (2012) Perepis' 2010: etnicheskij srez [Census 2010: The Ethnic Aspect]. Demoscope Weekly, 31.05.2012. Available at http://demoscope.ru/weekly/2012/0531/ tema01.php (accessed 27 May 2017).

Konstantin Kazenin - PhD, director, Center for Regional Studies and Urbanistics, The Russian Academy for National Economy and Public Administration, Moscow, Russian Federation. Email: kz@ranepa.ru 
Karpov Ju.Ju. (2010) Pereselenie gorcev Dagestana na ravninu: k istorii razvitija processa i socio-kul'turnym ego posledstvijam [The Migration of Dagestan Mountaineers to the Valley: The Historical and Social-Cultural Consequences]. In: Ju. Ju. Karpov (ed.) Tradicii narodov Dagestana v menjajushchemsja mire [The Traditions of the Peoples of Dagestan in the Developing World]. St. Petersburg: Peterburgskoe Vostokovedenie: 402-447.

Karpov Ju.Ju, Kapustina E.L. (2011) Gorcy posle gor [Mountaineers after Mountains]. St. Petersburg: Peterburgskoe Vostokovedenie.

Kazenin K.I. (2012) Elemeny Kavkaza: zemlja, vlast' i ideologija v severokavkazskikh respublikakh [Elements of the Caucasus: Land, Administration and Ideology in the Republics of North Caucasus]. Moscow: REGNUM.

Kazenin K. I. (2017) Rozhdaemost' v semjakh migrantov: dannye, gipotezy, modeli (obzor zarubezhnyx issledovanij) [Fertility in Migrant Families: Data, Hypotheses, and Models (An Overview of Foreign Studies)]. Demograficheskoe obozrenie [Demographic Review], 4 (4): 6-79.

Kazenin K. I., Kozlov V. A. (2016) Omolozhenie materinstva v Daghestane: tendencija ili artefakt [Decrease of Mother's Age at Birth in Dagestan: A Tendency or an Artifact?]. Demograficheskoe obozrenie [Demographic Review], 3 (3): 100-123.

Kazenin K. I., Kozlov V.A. (2017a) Vozrast materinstva v Dagestane: znachimost' etnicheskogo faktora v uslovijax modernizacii [The Age of the Motherhood in Dagestan: The Significance of Ethnicity under Modernization]. Narodonaselenie [Population], 21 (1):46-58.

Kazenin K. I., Kozlov V.A. (2017b) Osobennosti brachno-reproduktivnogo povedenija v Respublike Dagestan: ikh prichiny i social'no-ekonomicheskie posledstvija [The Special Characteristics of Marriage and Fertility in the Republic of Dagestan: Their Reasons and Their Socio-Economic Consequences]. Vestnik Instituta Ekonomiki RAN [Journal of Institute for Economy RAN], 11 (2): 65-81.

Kohler H.-P. (2000) Social Interaction and Fluctuations in Birth Rates. Population Studies, 54 (2): 223-238.

Kulu H. (2005) Migration and Fertility: Competing Hypothesis Reexamined. European Journal of Population Research, (21): 51-87.

Kulu H., Gonzalez-Ferrer A. (2014) Family Dynamics among Immigrants and their Descendants in Europe: Current Research and Opportunities. European Journal of Population, (30): 411-435.

Osmanov A. I. (2000) Agrarnye preobrazovanija v Dagestane i pereselenie gorcev na ravni$n u(20-70$-je gody XX v.) [Agricultural Reforms in Dagestan and the Migration of Mountaineers to the Valley (1920-1970)]. Makhachkala: DNC RAN.

Szołtysek M., Poniat R., Gruber S., Klüsener S. (2016). The Patriarchy Index: A New Measure of Gender and Generational Inequalities in the Past. MPIDR Working Papers-014. Avaliable at: https://www.researchgate.net/publication/312033180_The_Patriarchy_Index_a_new_measure_of_gender_and_generational_inequalities_in_the_past_updated (accessed 1 - Feb 2019$)$.

Zakharov S. V., Surkov S. V. (2009) Migracionnyj opyt i rozhdaemost' v poslevoennyx pokolenijax rossiajan [Migration Experience and Fertility in Russia's Post-War Generations]. In: S. V. Zakharov, T. M. Maleva, O. V. Sinjavskaja (eds.) Roditeli I deti, muzhchiny I zhenshchiny v semje i obshchestve, Vyp.2. [Parents and Children, Men and Women in the Family and in Society, Issue 2]. Moscow: NISP: 45-118. 